\title{
ПРОБЛЕМАТИКА ЛІНГВОАКСІОЛОГІЇ В ЗАХІДНІЙ ДОСЛІДНИЦЬКІЙ ТРАДИЦІЇ: АСПЕКТУАЛЬНИЙ ОГЛЯД
}

Ковтун О. В.

ВСТУП

Оцінка - ковзке та контекстно залежне поняття... Лаура Хідальго-Доунінг

Лінгвоаксіологія - це, як відомо, сфера лінгвістичних досліджень, що скеровані на системне вивчення оцінки та оцінних категорій, вербалізованих чи граматикалізованих у мові. Феномен цінності, проблеми аксіології привертають увагу дослідників 3 давніх часів. Зазначені проблеми науковці розглядали у фокусі численних філософських шкіл, їх відповідно інтерпретували і в парадигмі лінгвофілософії, і крізь призму інших актуальних напрямів мовознавства XX і XXI століть. Однак нині ще багато у цій сфері не пізнаного, зокрема неокресленою залишається й історія поступу лінгвоаксіології, насамперед у західній науковій традиції. Цю прогалину спробуємо частково ліквідувати.

У східнослов'янській дослідницькій традиції лінгвоаксіологію пов'язують передусім з напрацюваннями Ніни Арутюнової, яка першою здійснила фундаментальний концептуальний аналіз слів із семантикою оцінки 3 урахуванням західно-європейської лінгвофілософської парадигми в історичній перспективі. Названа дослідниця окреслила коло питань, що важливі для визначення специфіки категорії оцінки як категорії лінгвофілософської, зокрема вчена запропонувала: (1) опис принципів та формальної структури дефініцій оцінних і деонтичних предикатів; (2) інтерпретацію відносності поняттєвої дихотомії «добре»«погане»; (3) характеристику зв'язку оцінки 3 (а) природними властивостями об'єкта і (б) ціннісних і нормативних суджень 3 фактичними; (4) дескрипцію оцінної модальності; (5) характеристику (a) нормативної лексики та (б) лексики із семантикою оцінки в акті комунікації; (5) опис відсутності суперечностей у текстах, що містять оцінні й деонтичні поняття; (6) репрезентацію (а) структури та специфіки практичних суджень; (б) мовленнєвих функцій оцінних предикатів ${ }^{1}$.

\footnotetext{
${ }^{1}$ Арутюнова Н.Д. Типы языковых значений. Оценка. Событие. Факт. Москва : Наука, 1988. 341 с.
} 
Послідовниками Ніни Арутюнової в російському мовознавстві є Надія Аксенова $(2007)^{2}$, Олена Вольф $(2002)^{3}$, Тетяна Маркелова $(2013)^{4}$, Ельвіра Столярова $(1988)^{5}$, Віктор Шаховський $(2008)^{6}$ та інші.

В українському ж мовознавстві всебічний аналіз категорії оцінки в руслі прагматичної поліфункційної наукової парадигми на початку XX століття здійснила Тетяна Космеда $(2000)^{7}$, окресливши дослідницький напрям «аксіологічна прагмалінгвістика», що зумовило комплексне вивчення оцінних значень на різних мовних рівнях, а також у проєкції на мовлення 3 урахуванням комунікативних намірів адресанта в реалізації прагматичних завдань. Зазначена авторка задекларувала становлення української лінгвоаксіології, зокрема й теорії граматики оцінки, указавши на аксіологічний частиномовний потенціал слів ${ }^{8}$, започаткувавши власну наукову школу, діяльність якої здійснюється в руслі української лінгвістичної теорії цінностей відображення в мові ціннісних аспектів буття 9 .

Актуалізувавши напрацювання Тетяни Космеди, Оксана Халіман сфокусувала увагу на вивченні суто граматичних питань лінгвоаксіології у фокусі морфологічних категорій (морфологія оцінки).

Українські вчені інтерпретують граматику оцінки як новий науковий напрям, мета якого - усебічне дослідження системи граматичних засобів вираження оцінних значень 3 урахуванням їх прагматичних характеристик ${ }^{10}$. Зауважено, що «розробка теорії граматики оцінки передбачає комплексний опис граматичних засобів вираження оцінних значень, що забезпечить вироблення правил

${ }^{2}$ Аксенова Н.В. Оценочные смыслы в метафоре (на материале англоязычной литературы XX века) : автореф. дис. ... канд. филол. наук. Санкт-Петербург, 2007. 19 c.

3 Вольф Е.М. Функциональная семантика оценки. 2-е изд., доп. Москва : Едиториал УРСР, 2002. 280 с.

${ }^{4}$ Маркелова Т.В. Прагматика и семантика средств выражения оценки в русском языке : монография. Москва : Москов. гос. ун-т печати им. Ивана Федорова, 2013. 299 c.

5 Столярова Э.А. Лексико-семантическое поле оценки в разговорной речи. Словарные категории : сб. статей. Москва : Наука, 1988. С. 186-191.

6 Шаховский В.И. Категоризация эмоций в лексико-семантической системе языка, изд. 2, испр. и доп. Москва, URSS, 2008. 208 с.

${ }^{7}$ Космеда Т. Аксіологічні аспекти прагмалінгвістики: формування і розвиток категорії оцінки : монографія. Львів : ЛНУ ім. І. Франка, 2000. 349 с.

${ }^{8}$ Там само.

9 Халіман О.В. Граматика оцінки: морфологічні категорії української мови : монографія. Харків : Майдан, 2019. 458 с.

10 Космеда Т.А., Халіман О.В. «Граматика оцінки» як актуальна проблема сучасного мовознавства. Лінгвістичні студї. Донецьк : Донец. нац. ун-т, 2011. Вип. 22. С. 17-23. 
уживання граматичних одиниць в оцінних функціях та трактування закономірностей їх тлумачення» ${ }^{11}$.

До граматичних засобів вираження оцінки, як наголошує Оксана Халіман, належать i морфологічні одиниці, i синтаксичні конструкції, що логічно за традицією зумовлює поділ граматики оцінки на два підрозділи: морфологія оцінки й синтаксис оцінки ${ }^{12}$, що нерозривно пов'язані, оскільки «вторинні значення морфологічних форм (зокрема, оцінні) реалізуються в синтагматичних відношеннях» ${ }^{13}$. Оксана Халіман (2019) репрезентувала грунтовний опис усієї системи іменних та дієслівних граматичних категорій крізь призму граматики оцінки, показавши, зокрема, i функційне навантаження деяких стилістичних засобів, що створюють граматичну конотацію й відіграють ключову роль у моделюванні відповідних мовленнєвих жанрів ${ }^{14}$.

Проблематику лінгвоаксіології в українському мовознавстві досліджують, крім названих учених, також Юрій Булик $(2009)^{15}$, Жанна Краснобаєва-Чорна $\quad(2016)^{16}, \quad$ Ганна Приходько $\quad(2016)^{17}$, Дар'я Рязанцева (2013) ${ }^{18}$ та ін.

Мета статті - подати аспектуальний огляд формування лінгвоаксіології в західній дослідницькій традиції XX століття і донині, сфокусувавши увагу на найбільш авторитетних i цитованих дослідженнях ключових науковців.

\section{1. Становлення лінгвоаксіології в проскції на західну традицію 3 першої половини до 80-x років XX століття}

Учені запропонували чимало аксіологічних класифікацій мовного матеріалу, охарактеризували систему видів оцінки, продовжують удосконалювати iii 3 огляду на дослідницьку мету та завдання. Найбільш авторитетними у царині лінгвоаксіології вважають концепції

${ }^{11}$ Там само.

12 Халіман О.В. Граматика оцінки: морфологічні категорії української мови : монографія. Харків : Майдан, 2019. 458 с.

${ }_{13}$ Там само.

${ }^{14}$ Космеда Т. Переднє слово, або «морфологія оцінки» О.В. Халіман. Граматика оцінки: морфологічні категорії української мови : монографія. Харків : Майдан, 2019. С. 7-12.

15 Булик Ю.В. Рекламний текст у параметрах аксіологічної прагмалінгвістики : автореф. дис ... канд. філол. наук. Харків, 2009. 20 с.

16 Краснобаєва-Чорна Ж.В. Лінгвофраземна аксіологія: парадигмальнокатегорійний вимір : монографія. 2-е вид., випр. і доп. Вінниця : ТОВ «Нілан-ЛТД», 2016. 416 c.

${ }^{17}$ Приходько Г.І. Категорія оцінки в контексті зміни лінгвістичних парадигм : монографія. Запоріжжя : Кругозор, 2016. 200 с.

18 Рязанцева Д.В. Прикметник сучасної української мови у вимірах граматики оцінки : дис. ... канд. філол. наук : спец. 10.02.01. Харків, 2013. 
(1) Макса Шелера ${ }^{19}$ (Німеччина) та Хосе Ортега-і-Гассета ${ }^{20}$ (Іспанія), які реалізували феноменологічний підхід до дослідження проблем лінгвоаксіології; (2) Рене Ле Сенна ${ }^{21}$ (Франція) та Луї Лавеля ${ }^{22}$ (Франція): запропоновано реалістичний підхід 3 урахуванням лінгвоаксіологічної проблематики; (3) Мілтона Рокіча ${ }^{23}$ (США), який розробив психосоціальну дослідницьку перспективу лінгвоаксіології.

$\mathrm{У}$ середині XX століття в лексичній семантиці виразно почала домінувати логіка, або, точніше, той аспект логіки, що стосувався оцінки істини. Традиції Фердинанда де Соссюра та Ноема Хомського (structuralism and generative linguistics) увиразнили тенденцію щодо опису семантики природних мов: учені почали більше уваги звертати на аксіологічні опозиції, на кшталт: добре - погане, потворне красиве. Однак дослідження власне лінгвістичних аспектів аксіології ще не були актуалізовані ${ }^{24}$.

До останньої третини XX століття лінгвоаксіологія, у фокусі якої лінгвофілософська категорія оцінки, у західній мовознавчій традиції репрезентована лише епізодичними розвідками. Вербалізацію оцінки розглядали насамперед у фокусі теорії конотації чи лінгвоемоціології (вербалізації емоцій). У цей період значення оцінки більшість мовознавців досліджували в семантичній парадигмі як «приховані натяки на певні почуття» ${ }^{25}$ та «додаткові смисли» ${ }^{26}$, що безпосередньо не пов'язувалися 3 категоріями лінгвоаксіології ${ }^{27}$. Подібні наукові розвідки виконували в руслі структурної та генеративної лінгвістики. Однак деякі представники цих домінувальних лінгвістичних напрямів упродовж наступних 20-30 років усе-таки здійснювали свою наукову діяльність й у фокусі функційної лінгвістики 3 урахуванням особливостей вербалізації оціночних параметрів мовлення - «оціночної

19 Scheler Max. Der Formalismus in der Ethik und die Materiale Wertethik. 1913-1916. $872 \mathrm{p}$.

${ }^{20}$ Ortega y Gasset José. 1923. "Introducción a una estimativa: ¿qué son los valores?”. Revista de Occidente. IV, October. Madrid : Revista de Occidente. 1947. P. 315-335.

${ }^{21}$ Le Senne René. Traité de Morale Générale. Paris : Presses Universitaires de France. 1942. $757 \mathrm{p}$.

${ }^{22}$ Lavelle Louis. Traité des Valeurs. (2 vol.). Paris : Presses Universitaires de France. 1950-1955. 560 p.

${ }^{23}$ Rokeach Milton. The Nature of Human Values. New York : The Free Press, McMillan. 1973. 438 p.

24 Felices-Lago Ángel. Reformulation of the domain-level semantic pattern of axiological evaluation in the lexicon of English verbs. Hermes 30. 2003. P. 179-198.

${ }^{25}$ Pottier Bertrand. Linguistique Générale. Théorie et Description. Paris : Klincksieck. 1974. 340 p.

${ }^{26}$ Trujillo Ramón. El Campo Semántico de la Valoración Intelectual en Español. La Laguna : University of La Laguna Press. 1970. 557 p.

${ }^{27}$ Ullmann Stephen. Semantics. Oxford : Basil Blackwell. 1962. 278 p. 
системи» (Appraisal Framework). Це, зокрема, лінгвістична парадигма вивчення, опису та пояснення способів використання мовних засобів вираження оцінки, що пов'язані із системною граматикою ${ }^{28}$.

Питання лінгвоаксіології в західній лінгвістичній традиції порушуються в межах фундаментальних лінгвістичних напрямів.

Структурна лінгвістика. Серед перших дослідників лінгвоаксіологічної проблематики на початку XX століття виразно виокремлюється Шарль Баллі $(1913)^{29}$. Цей учений усвідомив, що здатність людини оцінювати (позитивно чи негативно) довкілля відіграє важливу роль не лише для прогресу, поступу людства, але й для формування й розвитку мови (мовлення). Науковець наголошував, що мислення людини, виражене в іiі мовленні, спонтанно сприймає «ідею оцінювання, тобто інстинкт збереження, який пов'язує все 3 нашим я, нашим життям, нашим добробутом» ${ }^{30}$. Цей інстинкт «просіює наші враження відповідно до суті поняття «корисність»: «Це добре, а це погано»; але іноді він приймає й більш досконалу форму: «Це правильно, а це неправильно». Просіювання думки крізь призму оцінки характерне для людської природи та необхідне для нашого існування. То як це не може бути не відображеним у мові?» (перекл. автор. $-O . K.)^{31}$. Таке риторичне питання поставив учений.

Шарль Баллі вказує на тісний взаємозв'язок між оцінними судженнями та вираженням у мові емоцій чи почуттів прихильності у всій гамі відтінків. Дослідник зауважив, що «...оцінні судження відрізняються від логічних, оскільки певною мірою вони завжди емоційні й ніколи їх не трактують як інтелектуальні продукти» (перекл. автор. $-O . K.)^{32}$. Науковець сприймає аксіологічний параметр як певний «тонкий феномен, що пронизує більшість мовних виразів (конотація), але водночас може бути й неприхованим (денотація), вербалізованим за допомогою системи мовних елементів, що виконують у мовленні особливу функцію» ${ }^{33}$.

Структурна семантика була глибоко вкорінена в європейській науці, особливо у Франції та Німеччині у середині XX століття. Французькі лінгвісти осмислювали процес інтеграції категорій суб'єктивності та аксіології в лексику, хоча цілісну теорію лінгвоаксіології на той час вони ще не розробили. Наприклад, Жорж Маторе запропонував

${ }^{28}$ Martin James and White Peter. The Language of Evaluation. Appraisal in English. New York : Palgrave Macmillan. 2005. 278 p.

${ }^{29}$ Bally Charles. Le langage et la vie. Atar, 1913. $111 \mathrm{p}$.

30 Bally Charles. Traité de Stylistique Française. (3rd. ed., 2 vol.) Paris : C. Klincksiek. 1951. 264 p.

31 там само.

${ }^{32}$ Bally Charles. El Lenguaje y la Vida. (5th. ed.) Buenos Aires : Losada. 1967. 250 p.

33 Bally Charles. Traité de Stylistique Française. (3rd. ed., 2 vol.) Paris : C. Klincksiek. 1951. 264 p. 
структуру поняттєвого поля “d'art et de technology vers 1765"34, актуалізувавши соціолінгвістичний підхід, однак не запропонував при цьому концептуальної методології. Він оперує поняттями «причина» (La raison), «почуття» (Le Sentiment), «відчуття» (Les sensations), «соціальність» (La socialité) та «чеснота» $(\text { La vertu })^{35}$. Побудоване Жоржем Маторе поняттєве поле репрезентувало вплив, який соціальні чинники справляють на аксіологічні виміри, зокрема, такі як відчуття, почуття, настрої та мораль, етика поведінки.

У 1955 році П'єр Гіро став одним 3 небагатьох франкомовних лінгвістів, які повстали проти соссюрівської інтерпретації категорії оцінки (valeur). На його думку, основне й контекстуальне значення не накладаються один на одного; у кожній конкретній ситуації формується одне значення - контекстуальне; уживаючись у певному контексті, слово репрезентує єдиний концептуальний образ. Але можна простежити й інші позапоняттєві асоціації, що, не змінюючи відповідної ідеї, лише забарвлюють ії. «...Ми називаємо їх оцінками на відміну від значення; оцінка - це позасемантична асоціація» (перекл. автор. - O.К. $)^{36}$. Оцінка в цьому разі позбавляється статусу значення, iї природа пояснюється крізь призму прагматики.

Семантика. Концепція «семантичного диференціалу» Чарльза Осгуда, Джорджа Сусі й Персі Танненбаума ${ }^{37}$ продемонструвала, що оцінка може виконувати домінувальну функцію в структурі значення ${ }^{38}$. Подальші дослідження довели, що емоції $є$ основними чинниками, які визначають характер інформації, а не просто ії модифікацію. Цю фундаментальну «знахідку» когнітивної психології, очевидно, ігнорували попередні покоління лінгвістів ${ }^{39}$. Наприклад, мовознавці соссюрівської традиції запропонували кілька формальних тверджень про центральну роль, яку відіграє аксіологічний компонент для моделювання значення лексичних одиниць природних мов, однак жодної важливої лінгвоаксіологічної теорії протягом цього періоду не було сформульовано.

34 Matoré G. La Méthode en Lexicologie. Domaine Français. Paris : Didier. 1953. $127 \mathrm{p}$.

35 Там само.

${ }^{36}$ Guiraud Pierre. La Sémantique. Paris : P.U.F. 1955. 118 p.

37 Osgood Charles, Suci George and Tannenbaum Percy. The Measurement of Meaning. Chicago : Illinois University Press. 1957. 342 p.

${ }^{38}$ Osgood Charles. The cognitive dynamic of synaesthesia and metaphor. Cognition and Figurative Language / Richard P. Honek and Robert R. Hoffman (eds). Hillsdale, New Jersey : Lawrence Erlbaum. 1980. P. 203-238.

39 Krzeszowski Tomasz P. Angels and Devils in Hell. Elements of Axiology in Semantics. Warsaw : Energeia. 1997. 298 p. 
У популярній монографії під назвою "Semantics" («Семантика», $1962)^{40}$ британський учений Стівен Уллманн поділяє всі лексеми на дві групи: (1) слова, що містять оцінний компонент значення, наприклад, халуnа (a hovel) - «невеличка хатина, дуже брудна, що потребує ремонту», нашкрябати (to scrawl) - «написати щось дуже швидко, не намагаючись зробити почерк охайним або легким для читання»; (2) слова-оцінки, де оцінне значення домінує, наприклад, це такі прикметники, як добрий, хоробрий, смішний, дурний, жахливий (good, brave, funny, stupid, horrible) та їхні антоніми. На думку зазначеного лінгвіста, у подібних лексемах емоційний елемент - це «їхнє головне семантичне значення» ${ }^{41}$.

Розвитку структурної семантики сприяли Євгеніо Козерю ${ }^{42}$ та Бернард Потьє ${ }^{43}$. Вони зосередили свою увагу на «класематиці» (Classematics) - відгалуженні структурної семантики, що повинна була вивчати класи слів, насамперед класи перехідних французьких дієслів. Керівник Тюбінгенської школи був першим, хто порушив проблему лінгвістичного опису категорії оцінки, яка репрезентована прикметником. На його думку, є «позитивні» та «негативні» класи прикметників, що слугують для побудови в авторській термінології «єднальних сполучень» - ідеться про сурядні сполучення з єднальним сполучником, наприклад: "bello е buопо” (благородний $i$ красивий), "grande e grosso" (великий i високий), "piccolo e brutto" (маленький i потворний) тощо, або для конструювання, за визначенням дослідника, «протиставних сполучень» - сурядних сполучень 3 протиставним сполучником, наприклад: “povero ma onesto" (бідний, але чесний) ${ }^{44}$.

Послідовник Євгеніо Козерю Горст Гекелер застосував його лінгвістичні розвідки для синхронного аналізу лексико-семантичної групи прикметників, що об’єднані значенням «вік людини», використавши для структуризації те, що він назвав «специфічним виміром, що може бути охарактеризований як оцінна інтерпретація (evaluative appreciation)» ${ }^{45}$ у поєднанні 3 критерієм розмежування віку оцінними протиставними семами «поважний» - «неповажний». Мовознавець намагався довести, що ідеться про «...компонент денотативного значення, який не має конотації» (перекл. автор. - O.K.) $)^{46}$.

${ }^{40}$ Ullmann Stephen. Semantics. Oxford : Basil Blackwell. 1962. 278 p.

${ }^{41}$ Там само.

${ }^{42}$ Coseriu Eugenio. Principios de Semántica Estructural. Madrid : Gredos. 1977. 246 p.

${ }^{43}$ Pottier Bertrand. Linguistique Générale. Théorie et Description. Paris : Klincksieck. 1974. $340 \mathrm{p}$.

${ }^{44}$ Coseriu Eugenio. Principios de Semántica Estructural. Madrid : Gredos. 1977. 246 p.

45 Geckeler Horst. Strukturelle Semantik und Wortfeldtheorie. Munich : Fink. 1971. $255 \mathrm{p}$.

46 там само. 
Роком раніше (1970) іспанець Рамон Трухільо в монографії “Еl Campo Semántico de la Valoración Intelectual en Español” («Семантичне поле інтелектуальної оцінки в іспанській мові») ${ }^{47}$ також досліджував соціально-етичний та інтелектуальний типи оцінки як опозицію позитивне - негативне з огляду діахронії, позначаючи їх, як (+) або (-), або (+/-). Це всебічне дослідження лексичної семантики засноване, головно, на принципах, установлених Свгеніо Козерю й застосованих до однієї з головних аксіологічних сфер - соціально-етичної. Рамон Трухільйо приділяє велике значення цьому аксіологічному поділу на емпіричному рівні, у своїх теоретичних постулатах він стверджує, що інтелектуальна оцінка - це лише сфера вивчення соціолінгвістики ${ }^{48}$.

Дослідження лексико-семантичного розряду дієслів зі значенням «пересування людини», структурованого німецьким мовознавцем Гердом Вотяком, містить розділ під назвою "Emotion as an influential meaning label in the corpus analysis" («Емоція як впливовий значеннєвий параметр у корпусному аналізі»). 3 огляду на природу досліджуваних дієслів, автор не торкався аксіологічних компонентів (позитивне негативне), а інтегрував емоційні та афективні особливості, що послідовно вербалізуються, які інші дослідники не враховували ${ }^{49}$.

Представник структурної семантики Бернард Потьє $(1974)^{50}$ запропонував розглядати аксіологічний чинник як специфічну модальність, яку можна було б внести до низки ключових лінгвоконцептуальних понять, а також до основних семантико-граматичних категорій (час, спосіб, власне модальність тощо). Однак, на його думку, цей чинник має особливу характеристику: за певних обставин він може впливати на інші модальності (епістемічні, фактативні, деонтичні тощо), що виокремлюються в академічній граматиці.

Румунський дослідник Сорін Статі (1979) - автор монографії "Sémantique des Adjectifs" («Семантика прикметників») ${ }^{51}$ - подав найбільш повну «інтуїтивну класифікацію» лексичних одиниць оцінної семантики ("the most complete intuitive classification of axiological lexical units in modern linguistics"), закцентувавши увагу виключно на прикметниках французької та інших романських мов. Однак він не використав аналітичної моделі дослідження, що могла б адекватно

${ }^{47}$ Trujillo Ramón. El Campo Semántico de la Valoración Intelectual en Español. La Laguna : University of La Laguna Press. 1970. 557 p.

${ }^{48}$ Там само.

49 Wotjak Gerd. Untersuchungen zur Struktur der Bedeutung. Berlin : AkademieVerlag. 1971. 343 p.

${ }^{50}$ Pottier Bertrand. Linguistique Générale. Théorie et Description. Paris : Klincksieck. 1974. 340 p.

51 Stati Sorin. La Sémantique des Adjectifs: Essai d'Analyse Componentielle Appliqué aux Langues Romanes. Paris : Jean Favard. 1979. 144 p. 
поєднати семантичні, синтаксичні та прагматичні параметри кожного виокремленого прикметника.

У статті під назвою "Connotation and lexical field analysis" («Конотація та аналіз лексичного поля», 1986) британська дослідниця Розмарі Сансом ${ }^{52}$ здійснила спробу продемонструвати опис прагматики значення в більш широких межах контрастивного аналізу лексикосемантичних полів. У цьому дослідженні вона виявила специфіку конотації в межах компонентів однієї лексико-семантичної мікросистеми. У процесі об'єднання денотата та конотата в одному й тому самому значенні дослідниця встановлює вісім підкатегорій, включаючи оцінний параметр, а також інші ознаки, що відповідали б «діастратичному» (варіації мовлення різних соціальних класів), «діафазному» (варіації мовлення за ступенем формальності) та «діатопічному» (варіації мовлення на географічному рівні) розрізненням, що описані Свгеніо Козерю ${ }^{53}$.

\section{2. Розвиток лінгвоаксіології в проскції на західну традицію 3 90-х років ХХ століття до 2020 р.}

Когнітивна лінгвістика. Вивчаючи історію досліджень категорії оцінки, актуалізуємо напрацювання Джорджа Лакоффа у сфері когнітивної семантики 3 урахуванням проблематики лінгвоаксіології. Цей учений вивчає вербалізацію мислення крізь призму категорій мови. Його підхід базувався на трирівневій ієрархії цінностей: (1) чуттєвий досвід, (2) життя та здоров'я, (3) духовний рівень ${ }^{54}$.

Досліджуючи теорію концептів, він протиставляє традиційне трактування цього поняття новому, за яким, на його думку, до набору сталих сутнісних ознак потрібно додати чуттєвий образ (емоційну оцінку), порівн.: «Теорія прототипів змінює наше уявлення про найбільш фундаментальну здатність людини до категоризації, а разом 3 нею наше уявлення про те, чим $\epsilon$ людський розум i мислення. Мислення на Заході тривалий час уважають чимось безтілесним й абстрактним, віддаленим, 3 одного боку, від сприйняття й тіла, від культури, а 3 іншого - від механізмів уяви, наприклад, від метафоричної та метонімічної образності» (перекл. автор. - O.K. $)^{55}$.

Томаш Павел Кшешовський зауважив, що попередні дослідники, які працюють у галузі когнітивної семантики, загалом не акцентували уваги на питаннях, що стосуються цінностей, оцінки та специфіки

${ }^{52}$ Sansome Rosemary. Connotation and lexical field analysis. Cahiers de Lexicologie. XLIX (II). 1986. P. 13-33.

${ }^{53}$ Там само.

${ }^{54}$ Lakoff G. Women, fire, and dangerous things. What Categories Reveal about the Mind. Chicago; London : The University of Chicago Pres. 1987.614 p.

55 там само. 
їхнього омовлення. Науковець дійшов висновку, що такі поняття, як «конотативне значення» (емоційне, афективне та інші), а також, власне, «аксіологія», не були дослідницькими об'єктами, а це значить, що лінгвоаксіологія на той час не була виокремлена як самостійний напрям $^{56}$. Названий науковець вивчає цінності у фокусі когнітивної семантики, напрацьовуючи фреймову методику й досліджуючи аксіологічні компоненти. Дослідник розглядає ідеалізовані когнітивні моделі, що відображають систему цінностей ${ }^{57}$.

Соціолінгвістика. Традиційні дослідження в галузі лексики переважно скеровані на аналіз основних категорій аксіології, що вербалізуються в дихотомії позитивне - негативне з урахуванням конотації. Уільям Лабов ${ }^{58}$ наводить перелік лінгвістичних особливостей, пов'язаних зі специфікою вияву оцінки в розмовному мовленні, а дослідження, спроєктовані на дискурс, дали змогу системно вивчити способи передачі оцінки мовними засобами. У цих працях основна увага зосереджена на способах ідентифікації типу оцінки: для Уільяма Лабова такий тип оцінки переважно нерелевантний (сам факт наявності оцінки), а для Майкла Хої ${ }^{59}$ та Майкла Джордана ${ }^{60}$ питання полягає у визначенні характеру оцінки (позитивної чи негативної). Поза увагою дослідників залишилося питання мотивації оцінки. Ця лакуна здається дивною, ураховуючи ступінь того, наскільки аксіологічний аспект $є$ суттєвим для мовлення.

Дискурсна лінгвістика. В останне десятиліття XX та з перших років XXI століття лінгвістичне дослідження багатофункційної категорії оцінки значно активізувалося. Це демонструють праці Сьюзан Ханстон і Джоффа Томпсона (2000) $)^{61}$, Джеймса Мартіна $\left(2002^{62}, 2004^{63}\right.$,

${ }^{56}$ Krzeszowski Tomasz P. The axiological aspect of idealized cognitive models. Meaning and Lexicography / Jerzy Tomaszczyk and Barbara Lewandowska (eds). Amsterdam : John Benjamins. 1990. P. 135-165.

${ }^{57}$ Там само.

58 Labov William. Language in the inner city. Philadelphia : University of Pennsylvania Press. 1972. P. 354-396.

${ }^{59}$ Hoey Michael. On the surface of discourse. London : George Allen and Unwin. 1983. 219 p.

${ }^{60}$ Jordan Michael. Some discourse patterns and the signalling of the AssessmentBasis relation. Patterns of text: in honour of Michael Hoey / Eds. Mike Scott and Geoff Thompson. Amsterdam : John Benjamins. 2001. P. 159-92.

${ }_{61}$ Hunston Susan. Evaluation and the planes of discourse: Status and value in persuasive texts. Evaluation in Text. / ed. Susan Hunston and Geoff Thomson. Oxford and New York : Oxford University Press. 2000. P. 176-206.

${ }^{62}$ Martin J. Blessed are the Peacemakers: Reconciliation and Evaluation. Research and Practice in Professional Discourse / Christopher N Candlin (Eds.). Tat Chee Avenue, Kowloon, Hong Kong : City University of Hong Kong Press. 2002. P. 187-227.

${ }^{63}$ Martin J. Sense And Sensibility: Texturing Evaluation. Language, Education and Discourse: Functional Approache / Joseph A. Foley (Eds.). London : Nicholson Museum, University of Sydney. 2004. P. 270-304. 
$\left.2010^{64}\right)$, Майкла Халідея і Крістіана Метьєсена (2004) $)^{65}$, Сьюзан Ханстон $\left(2008^{66}, 2011^{67}, 2019^{68}\right)$, Джеймса Мартіна і Пітера Уайта $(2005)^{69}$, Роберта Енглберстона $(2007)^{70}$ і Моніки Беднарек $\left(2006^{71}\right.$, $\left.2008^{72}, 2009^{73}\right)$, Бруно Бари $(2010)^{74}$, Елени Котос $(2014)^{75}$, Пітера Уайта $\left(2015^{76}, 2016^{77}\right)$, Рут Бріз та Інесс Олзи $(2017)^{78}$ та інших.

У зазначений період дослідження категорії оцінки проєктувалося на взаємозв'язок 3 контекстом, виникненням нового смислового навантаження в дискурсі. Розвивається дискурс-аналіз крізь призму категорії оцінки, тобто в лінгвоаксіології окреслюється напрям дискурсивної аксіології й увага концентрується на дослідженні наукового стилю, точніше, нейтралізації стильової диференціації. Нові підходи запропонували Джон Сінклер $(1981)^{79}$, Пуленг Тетели $(1997)^{80}$,

${ }^{64}$ Martin J., Zappavigna M., Dwyer P. Negotiating evaluation: story structure and appraisal in youth justice conferencing. Appliable Linguistics / Mahboob, Ahmar and Knight, Naomi K. (Eds.). London : Continuum. 2010. P. 44-75.

${ }_{55}$ Halliday Michael and Christian M.I.M. Matthiessen. Introduction to Functional Grammar. 3-rd edition. London : Edward Arnold. 2004. 689 p.

66 Hunston Susan. The evaluation of status in multi-modal speech. Functions of Language, 15. 2008. P. 64-83.

${ }^{67}$ Hunston Susan. Corpus Approaches to Evaluation: phraseology and evaluative language. Routledge. 2011. 212 p.

68 Hunston Susan. Language patterns and ATTITUDE revisited: adjective patterns, attitude and appraisal. Functions of Language. 26, 3. 2019. P. 343-371.

${ }^{69}$ Martin James and White Peter. The Language of Evaluation. Appraisal in English. New York : Palgrave Macmillan. 2005. 278 p.

${ }^{70}$ Englebretson Robert. Stancetaking in Discourse. Amsterdam/Philadelphia : John Benjamins. 2007. 323 p.

${ }_{71}$ Bednarek Monika. Evaluation and cognition: Inscribing, evoking and provoking opinion. Language and Memory. Aspects of Knowledge Representation. Hanna Pishwa / (ed.). Berlin : Mouton de Gruyter. 2006. P. 187-221.

${ }_{2}$ Bednarek Monika (ed.). Evaluation in Text Types. Special Issue of Functions of Language 15.1. Amsterdam : John Benjamins. 2008. 192 p.

${ }^{73}$ Bednarek Monika. Dimensions of evaluation. Cognitive and linguistic perspectives. Pragmatics and Cognition 17 (1). 2009. P. 146-175.

${ }_{74}$ Bara B. Cognitive Pragmatics: The Mental Processes of Communication. USA : MIT Press, 2010. 485 p.

${ }_{75}$ Cotos Elena. Genre-based automated writing evaluation for L2 research writing: From design to evaluation and enhancement. Basingstoke, UK : Palgrave Macmillan. 2014. 283 p.

${ }^{76}$ White P.R.R. Appraisal Theory. The International Encyclopedia of Language and Social Interaction / Tracy, K. (Ed.). John Wiley \& Sons. 2015. P. 1-7.

${ }^{77}$ White P.R.R. Evaluative contents in verbal communication. Verbal communication. 2016. Vol. 3. P. 77-96.

${ }^{78}$ Breeze R., Olza I. Evaluation in media discourse. European perspectives. Berlin : Peter Lang, 2017. 286 p.

${ }^{79}$ Sinclair John. Planes of discourse. The two-fold voice: essays in honor of Ramesh Mohan / ed. S.N.A. Rizvi. Salzburg : University of Salzburg. 1981. P. 70-89.

${ }^{80}$ Thetela Puleng. Evaluated entities and parameters of value in academic research articles. English for Specific Purposes. 16. 1997. P. 101-118. 
Сьюзан Ханстон (2000) $)^{81}$ та Сьюзан Худ (2004) ${ }^{82}$. Джон Сінклер увів поняття «автономна площина» (the autonomous plane), де мовець носій інформації, який переповідає слухачеві зміст тексту, та «інтерактивна площина» (the interactive plane), де мовець виступає в ролі творця тексту та інформує слухача про його структуру, тобто йдеться про те, що може оцінюватися і які ролі виконують мовці та слухачі в процесі оцінювання.

Спираючись на репрезентовану вище ідею Джона Сінклера, Сьюзан Ханстон виокремила «інтерактивну оцінку» (the interactive evaluation) як мовний матеріал, що допомагає моделювати аргументи. 3 точки зору дослідниці, оцінки, притаманні інтерпретації зовнішнього світу («автономній площині» - the autonomous plane), відображають ідеологію тієї частини суспільства, до якої належить мовець ${ }^{83}$. Сьюзан Ханстон проаналізувала різні типи дискурсу: атрибуцію (мовлення, змодельоване іншим), аверральність (власне мовлення особи) та систему жанрів (факти, інтерпретація, припущення, оцінка або рекомендація).

Напрацювання Сьюзан Ханстон плідно використала Пуленг Тетела для дослідження оціночного смислу та способів його реалізації в науковому дискурсі. Учена впровадила терміни: (а) «оцінка, орієнтована на тему» - OOT (TOE: topic-oriented evaluation) для аксіологічної інтерпретації реального світу; (б) «оцінка, орієнтована на дослідження» - ОOД (ROE: research-oriented evaluation) безпосередньо пов'язана 3 дослідницьким дискурсом та його метою ${ }^{84}$.

Пуленг Тетела запропонувала опозицію «світ контексту» i «реальний світ». Ключовим критерієм для розмежування ООТ (ТОЕ) i OOД (ROE), на думку вченої, є те, що при ООД оцінку проводить дослідник, тоді як позитивний чи негативний ООТ - це те, про що дослідник просто повідомляє й що саме по собі є нейтральним з огляду на оціночний вимір ${ }^{85}$.

Згодом Сьюзан Худ розвинула поняття Пуленг Тетели про ООД та ООТ, але використала дещо іншу термінологію. Вона замінила термін

${ }^{81}$ Hunston Susan. Evaluation and the planes of discourse: Status and value in persuasive texts. Evaluation in Text. / ed. Susan Hunston and Geoff Thomson. Oxford and New York : Oxford University Press. 2000. P. 176-206.

${ }^{82}$ Hood Susan. Appraising Research: Taking a stance in academic writing. Sydney : University of Technology. PhD thesis. 2004. 227 p.

${ }^{83}$ Hunston Susan. Evaluation and the planes of discourse: Status and value in persuasive texts. Evaluation in Text. / ed. Susan Hunston and Geoff Thomson. Oxford and New York : Oxford University Press. 2000. P. 176-206.

${ }^{84}$ Thetela Puleng. Evaluated entities and parameters of value in academic research articles. English for Specific Purposes 16. 1997. P. 101-118.

${ }^{85}$ Там само. 
OOД (ROE) на більш коректний, на їі думку, а саме: «поле досліджень»= FR (Field of Research), а OOT (TOE) - на «поле галузі» = FD (Field of Domain $^{86}$. Ідеї зазначених дослідників важливі для розробки принципів аксіологічного контекстуального аналізу. Однак важко вирішити, який із чотирьох підходів, використаних Джоном Сінклером («автономна площина» - the autonomous plane та «інтерактивна площина» - the interactive plane), Сьюзан Ханстон («інтерактивна оцінка»- the interactive evaluation), Пуленг Тетелою («оцінка, орієнтована на тему» - topicoriented evaluation і «оцінка, орієнтована на дослідження»-researchoriented evaluation) та Сьюзан Худ («поле досліджень» - Field of Research і «поле галузі» - Field of Domain), був найефективнішим, оскільки всі вони викликали бурхливі дискусії і неоднозначне потрактування.

У 2004 було опубліковано працю "Introduction to Functional Grammar” («Вступ до функційної граматики”) Майкла Халідея і Крістіана Метьєсена ${ }^{87}$, у якій автори частково описують морфологічні та синтаксичні механізми породження значення оцінки. Вони аналізують: (1) оцінні іменники, іменні номінації якостей, (2) іменні номінації системи цінностей 3 урахуванням полярної опозиції позитивне - негативне, (3) процес вербалізації модальності, (4) значення синтаксичних категорій 3 урахуванням специфіки виконання ними аксіологічних функцій, (5) оцінні значення в локальному дискурсивному середовищі, що виражена відповідними частинами мови. Перераховані способи моделювання значення оцінки з урахуванням граматичних категорій залишилися практично не описаними, проте послугували поштовхом та джерелом до подальших досліджень граматики оцінки, зокрема праць Сюзан Ханстон $\left(2008^{88}\right.$, $\left.2019^{89}\right)$, Хідальго-Доунінг $(2015)^{90}$ та інших.

У статті "Dimensions of evaluation” («Виміри оцінки») Моніки Беднарек ${ }^{91}$ охарактеризовано специфіку омовлення емоційного та раціонального типів оцінки. Названа авторка наголошує, що оцінка

${ }^{86}$ Hood Susan. Appraising Research: Taking a stance in academic writing. Sydney : University of Technology. PhD thesis. 2004. 227 p.

${ }^{87}$ Halliday Michael and Christian M.I.M. Matthiessen. Introduction to Functional Grammar. 3-rd edition. London : Edward Arnold. 2004. 689 p.

88 Hunston Susan. The evaluation of status in multi-modal speech. Functions of Language 15. 2008. P. 64-83.

${ }^{89}$ Hunston Susan. Patterns, constructions and local grammar: a case study of “evaluation". Applied Linguistics. 40, 4. 2019. P. 567-593.

${ }^{90}$ Hidalgo Downing Laura. Grammar and Evaluation. The Encyclopedia of Applied Linguistics / Edited by Carol A. Chapelle. December 2015. URL: https://doi.org/10.1002/9781405198431.wbeal1471 (дата звернення: 13.11.2020).

${ }^{91}$ Bednarek Monika. Dimensions of evaluation. Cognitive and linguistic perspectives. Pragmatics and Cognition 17 (1). 2009. P. 146-175. 
лежить в основі категоризації понять, які виявляються в мовленні. Вона описує прямий зв'язок між цінностями та мовою й показує, що вираження значення оцінки тісно пов'язане 3 емоціями. Процес оцінювання, зрозуміло, має антропоцентричний характер, оскільки, оцінюючи суб'єкт чи об'єкт, людина має «пропустити його ознаки крізь свою свідомість» (перекл. автор. - O.К. $)^{92}$. Але в кожному разі очевидно, що емоції є відображенням конкретної системи цінностей, яка $\epsilon$ закономірною властивістю певного дискурсу або може очікуватися, бути потенційною в межах відповідної дискурсивної практики. Тоді ця сукупність цінностей, як пояснює Моніка Беднарек, «стратегічно пов'язана із самопрезентацією <..> або є конвенціоналізованим, буденним дискурсом» (перекл. автор. - О.К. $)^{93}$. Отже, «мова оцінки» (мовлення, у якому виражаються оціночні смисли) є не лише дзеркалом індивідуального мислення («особистого розуму»), але й відповідного «соціального розуму» чи культури.

Важливим внеском у розробку теорії граматики оцінки вважаємо те, що Моніка Беднарек виокремлює зразки прикметників, іменників та дієслів, які використовуються для вербалізації, граматикалізації оцінного повідомлення після отриманого «емоційного досвіду» $(A f f e c t)^{94}$, проте вона не описує самого процесу вербалізації оцінки та не виявляє специфіки оціночного використання іменних та дієслівних граматичних категорій.

На думку Бруно Бари, можливість словесного спілкування завжди реалізується в конкретній ситуації, контексті, що $\epsilon$ внутрішньою притаманною характеристикою комунікації. Комунікативний аспект мови означає існування уніфікованої структури лінгвістичних одиниць, об'єднаних взаємозв'язком значеннєвого i формального планів ${ }^{95}$. Досліджуючи проблематику прагмалінгвістики у фокусі ментальних процесів комунікації, Бруно Бара разом зі своєю дослідницькою групою розробили новий «оцінювальний комплект» $\mathrm{ABaCo} \mathrm{(Assessment} \mathrm{Battery} \mathrm{for}$ Communication - оцінювальний комплект для спілкування), що може бути використаний для оцінювання системи здібностей, компетенцій, задіяних у спілкуванні, включаючи широкий спектр прагматичних явищ та комунікативних способів. АВаСо складається 3 п'яти шкал оцінки -

${ }^{92}$ Bednarek Monika. Dimensions of evaluation. Cognitive and linguistic perspectives. Pragmatics and Cognition. 17 (1). 2009. P. 146-175.

93 Bednarek Monika. Emotion talk and emotional talk: Cognitive and discursive perspectives. Language and Social Cognition. Expression of the Social Mind / Hanna Pishwa (ed.). Berlin : Mouton de Gruyter. 2009. P. 395-431.

${ }^{94}$ Там само.

95 Bara B. Cognitive Pragmatics: The Mental Processes of Communication. USA : MIT Press, 2010. 485 p. 
лінгвістичної, екстралінгвістичної, паралінгвістичної, дискурсивної та текстуальної, - які враховують насамперед особливості вербалізації таких поняттєвих феноменів, як обман, іронія, соціальна відповідність тощо 96.

Досліджуючи емоційний чинник вербальної комунікації, Пітер Уайт наголосив: стає очевидним факт, що комунікативний і когнітивний підходи актуалізуються синкретично. У зв'язку із цим функціювання оціночних висловлювань набуває особливого значення, оскільки оцінка різних фрагментів світу $\epsilon$ одним 3 найважливіших компонентів пізнавальної діяльності індивіда ${ }^{97}$. Оцінка - це процес, який охоплює весь зовнішній світ, довкілля і своєрідно виражається в метамові кожної науки. Це підтверджується тим фактом, що ціннісна орієнтація здебільшого сприяла розвитку системи напрямів не тільки в царині лінгвістики, але також і комп'ютерних технологій, генної інженерії та багатьох інших сфер науки. Вона вказує на стійку інтеграцію наукових знань у межах когнітивної парадигми, що сформувалася як міждисциплінарна (когнітивна) наука ${ }^{98}$.

Висловлену думку поділяють Рут Бріз та Інесс Олза, які слушно вважають, що оцінка - надважливий вид пізнавальної діяльності, оскільки в епістеміологічному плані кожний пізнавальний акт виражає ставлення мовця до описуваного об'єкта, тобто містить акт оцінки ${ }^{99}$. Дослідники зауважують: $€$ вагомі докази того, що з'являються закономірності, які одночасно відображають і поширюють оціночні парадигми, що раніше спостерігалися в друкованих та ефірних 3МI.

Отже, аналіз дискурсу дає змогу запропонувати ефективну та різноманітну методику для виокремлення типів оцінки як цілісної системи, що вербалізується в медіатекстах, та виявити способи, якими ці типи моделюються, відображаючи інтерактивні зв'язки ${ }^{100}$. Названі дослідниці вивчали оцінну функцію мовних засобів лише в публічних дискурсах медіасфери й при цьому врахували деякі тенденції оціночної риторики, застосовуючи систему аналітичних дослідницьких підходів. Однак їхня праця значно розширила сучасні знання щодо розуміння процесу оцінювання в різних сферах публічного мовлення.

${ }^{96}$ Bara B. Cognitive Pragmatics: The Mental Processes of Communication. USA : MIT Press, 2010. 485 p.

${ }^{97}$ White P.R.R. Evaluative contents in verbal communication. Verbal communication. 2016. Vol 3. P. 77-96.

${ }^{98}$ Там само.

${ }^{99}$ Breeze R., Olza I. Evaluation in media discourse. European perspectives. Berlin : Peter Lang, 2017. 286 p.

${ }^{100}$ Breeze R., Olza I. Evaluation in media discourse. European perspectives. Berlin : Peter Lang, 2017. 286 p. 
Досліджуючи категорію оцінки, учені звертають увагу на граматичні засоби вираження оцінних значень, оскільки, як уважає Лаура Хідальго Доунінг, саме граматика надає користувачам лінгвістичні (лексико-граматичні, зокрема морфосинтаксичні) ресурси для вираження значення, побудови речень та текстів, а також для спілкування з іншими носіями мови. Для вираження оцінки мовці, безперечно, активно використовують граматичні ресурси ${ }^{101}$. Дослідниця підкреслює, що вияв специфіки моделювання оцінного значення граматичними засобами $є$ складним, достатня увага якому почала приділятися лише останнім часом. На думку Лаури Хідальго Доунінг, основна проблема пов'язана 3 контекстною залежністю категорії оцінки від специфіки вияву ії в мовленні.

Отже, схоже, серед науковців існує консенсус у тому, що оцінка $\epsilon$ особливо «ковзким та контекстно залежним поняттям» (перекл. автор. - О.К.). Оцінні значення та смисли мають тенденцію своєрідно поширюватися в різних типах дискурсу, а не лише фокусуватися в конкретних лексичних чи граматичних одиницях мови ${ }^{102}$.

Складність зв'язку між категоріями граматики та категорією оцінки переконливо пояснює Сьюзан Ханстон, стверджуючи, що виявити специфіку вираження категорії оцінки в мовленні (дискурсі) надзвичайно важко, оскільки не існує описаного набору мовних форм (формул), граматичних чи лексичних, які охоплювали б весь діапазон вираження значень оцінки. Однак на матеріалі української мови це частково здійснила Оксана Халіман ${ }^{103}$.

Сьюзан Ханстон помітила закономірність, що прикметники та прислівники часто виражають оцінне значення, але не кожен прикметник та прислівник вербалізує оцінку, та не всі типи оцінки можна ідентифікувати саме так. Насправді, оцінка часто виражається кумулятивно та імпліцитно, неявно ${ }^{104}$. На думку названої вченої, важливим $\epsilon$ те, що, хоча типову лексику можна ідентифікувати в кожній конструкції прикметників 3 іншими словами, значення «належить» усе-таки граматичній конструкції, а не лексиці105. У своїх останніх розвідках

${ }^{101}$ Hidalgo Downing Laura. Grammar and Evaluation. The Encyclopedia of Applied Linguistics / Edited by Carol A. Chapelle. December 2015. URL: https://doi.org/10.1002/9781405198431.wbeal1471 (дата звернення: 13.11.2020).

${ }_{102}$ Там само.

103 Халіман О.В. Граматика оцінки: морфологічні категорії української мови : монографія. Харків : Майдан, 2019. 458 с.

${ }^{104}$ Hunston Susan. Corpus Approaches to Evaluation: phraseology and evaluative language. Routledge. 2011. 212 p.

105 Hunston Susan. Patterns, constructions and local grammar: a case study of “evaluation”. Applied Linguistics. 40, 4. 2019. P. 567-593. 
Сьюзан Ханстон досліджує прикметники та створює «локальну граматику оцінки» (a local grammar of evaluation). Дослідниця пояснює, що «локальна граматика - це завжди граматика дискурсивної функції. Тому вона тісно пов'язана 3 мовленнєвим актом. Отже, локальна граматика оцінки спрямована на опис найяскравіших форм вираження оцінного значення» (перекл. автор. - O.K.) ${ }^{106}$. Очевидно, поняття «граматика оцінки» Сьюзан Ханстон відрізняється від терміна, випрацюваного в українському мовознавстві Тетяною Космедою та Оксаною Халіман, і хоча вчена не дає свого визначення, однак, проаналізувавши іi погляди, можемо стверджувати, що під «локальною граматикою оцінки» дослідниця розуміє такий принцип опису категорії оцінки, який проєктується на конкретні граматичні категорії певної частини мови, як це продемонструвала названа вище авторка, описавши прикметники.

\section{ВИСНОВКИ}

У площині східнослов'янського мовознавства, зокрема російського й українського, лінгвоаксіологія досліджена грунтовніше, а західна традиція виглядає дещо бідніше, однак можна виокремити такі етапи становлення лінгвоаксіології в проєкції на західну традицію:

1. Перша половина XX століття - спорадичні дослідження аксіологічних параметрів у мові; виокремлення типів оцінних значень; актуалізація функційного підходу, сфокусованого на «оціночній системі» (Appraisal Framework).

2. 50-80-ті pp. ХX століття - період становлення структурної семантики; інтеграція суб'єктивності та аксіологічних параметрів у структуру лексичного значення; визначення поняття оцінки; визнання факту, що оцінка може виконувати домінувальну функцію в структурі значення; дослідження лінгвоаксіології у фокусі стилістики та лінгвоемоціології.

3. 90-ті pp. XX століття - початок XXI століття - інтерпретація оцінки у фокусі когнітивної лінгвістики; дослідження лінгвоаксіології крізь призму дискурсивної лінгвістики; вивчення контексту та його ролі у вияві характеру, типу оцінки в різних типах дискурсу, зокрема в науковому, побутовому та медійному.

4. 2000-2020 рр. - дослідження системи видів оцінки, механізмів іï породження, процесів вербалізації; поглиблення дискурсивної аксіології; становлення й розвиток граматики оцінки.

Питання лінгвоаксіології порушуються під час розробки таких напрямів, як структуралізм (Шарль Баллі, Жорж Маторе, П'єр Гіро), семантика (Чарльз Осгуд, Джордж Сус, Персі Танненбаум, Стівен

106 Там само. 
Уллманн, Евгеніо Козерю, Бернард Потьє, Горст Гекелер, Рамон Трухільо, Герд Вотяк, Сорін Статі, Розмарі Сансом), когнітивна лінгвістика (Джордж Лакофф, Томаш Кшешовський, Пітер Уайт, Рут Бріз, Інесс Олза), соціолінгвістика (Уільям Лабов, Майкл Хої та Майкл Джордан, Пітер Уайт), дискурсивна лінгвістика (Джон Сінклер, Пуленг Тетела, Сьюзан Ханстон, Моніка Беднарек, Джеймс Мартін, Пітер Уайт, Майкл Халідей, Бруно Бара, Рут Бріз, Інесс Олза, Лаура Хідальго-Доунінг).

Залежно від методології наукових шкіл західної традиції аксіологічна лінгвістика напрацьовувала певну усталену метамову, однак дослідники пропонують й авторські терміни, які ще не стали традиційними й не сприйняті східнослов'янським мовознавством, зокрема: «оціночна система» - Appraisal Framework (Майкл Халлідей, Джеймс Мартін і Пітер Уайт), «класематика»-Classematics (Свгеніо Козерю), «оцінна інтерпретація» - evaluative appreciation (Горст Гекелер), «автономна площина» - the autonomous plane та «інтерактивна площина» - the interactive plane (Джон Сінклер), «інтерактивна оцінка» - the interactive evaluation (Сьюзан Ханстон), «оцінка, орієнтована на тему» - topic-oriented evaluation, і «оцінка, орієнтована на дослідження» - research-oriented evaluation (Пуленг Тетела), «поле досліджень» - Field of Research та «поле галузі»-Field of Domain (Сьюзан Худ), «мова оцінки» (Моніка Беднарек), «локальна граматика оцінки» - a local grammar of evaluation (Сьюзан Ханстон). Можемо констатувати, що більшість із цих термінів ще не зафіксовані в словниках лінгвістичних термінів і потребують уточнення та розробки.

У західній лінгвістичній традиції простежуємо наявність фрагментарних праць з лінгвоаксіології та граматики оцінки (Майкл Халлідей, Джеймс Мартін, Пітер Уайт, Сьюзан Ханстон, Лаура Хідальго-Доунінг), однак фундаментальні монографічні дослідження, що були б присвячені проблематиці лінгвоаксіології, відсутні, на відміну від мовознавства східнослов'янського.

Обсяг наукових праць, присвячених аналізу процесу вербалізації, граматикалізації, моделюванню оцінки морфологічними й синтаксичними засобами, останніми роками свідчить про зацікавленість цією проблемою, що залишалася поза прискіпливою увагою в західній лінгвістичній традиції і заслуговує активного вивчення сьогодні. Нагальною залишається проблема доповнення вже існуючої теорії, присвяченої граматичним механізмам породження оцінки та дослідженню всього граматичного потенціалу мови крізь призму граматики оцінки на базі англійської мови.

Важливим i перспективним уважаємо розробку нового лінгвістичного напряму - контрастивної граматики оцінки, що може 
бути здійснене на матеріалі слов'янських і неслов'янських мов, адже порівняння граматичних засобів експлікації оцінки слугуватиме глибшому вивченню проблеми, розумінню внутрішньої суті мови, дасть змогу повно описати термінологійне поле метамови лінгвоаксіології, наочно продемонструє частотність використання моделей вербалізації та граматикалізації оцінних засобів у порівнюваних мовах, що сприятиме вирішенню важливих лінгвістичних проблем та проблем теорії й практики перекладу.

\section{АНОТАЦІЯ}

У дослідженні запропоновано аспектуальний огляд формування лінгвоаксіології в західній дослідницькій традиції XX століття і донині, виокремлено етапи iï становлення, розглянуто авторські терміни, які функціюють у наукових працях, однак ще не зафіксовані в словниках лінгвістичних термінів і потребують уточнення та розробки. Сфокусувавши увагу на найбільш авторитетних i цитованих дослідженнях ключових науковців, задіяних у сфері лінгвоаксіології, висновкуємо, що в західній лінгвістичній традиції простежуємо наявність фрагментарних праць з лінгвоаксіології та граматики оцінки, однак фундаментальні монографічні дослідження, присвячені проблематиці лінгвоаксіології, відсутні, на відміну від мовознавства східнослов'янського. Нагальною залишається проблема доповнення вже наявної теорії, присвяченої граматичним механізмам породження оцінки та дослідженню всього граматичного потенціалу мови крізь призму граматики оцінки на базі англійської мови. Важливим і перспективним уважаємо розробку нового лінгвістичного напряму контрастивної граматики оцінки, що може бути здійснене на матеріалі слов'янських i неслов'янських мов, адже порівняння граматичних засобів експлікації оцінки слугуватиме глибшому вивченню проблеми, розумінню внутрішньої суті мови, дасть змогу повно описати термінологійне поле метамови лінгвоаксіології, наочно продемонструє частотність використання моделей вербалізації та граматикалізації оцінних засобів у порівнюваних мовах, що сприятиме вирішенню важливих лінгвістичних проблем та проблем теорії й практики перекладу.

\section{ЛITЕРАТУРА}

1. Аксенова Н.В. Оценочные смыслы в метафоре (на материале англоязычной литературы XX века) : автореф. дис. ... канд. филол. наук. Санкт-Петербург, 2007. 19 с.

2. Арутюнова Н.Д. Типы языковых значений. Оценка. Событие. Факт. Москва : Наука, 1988. 341 с. 
3. Булик Ю.В. Рекламний текст в параметрах аксіологічної прагмалінгвістики : автореф. дис. ... канд. філол. наук. Харків, 2009. 20 с.

4. Вольф Е.М. Функциональная семантика оценки. 2-е изд., доп. Москва : Едиториал УРСР, 2002. 280 c.

5. Загнітко А. Словник сучасної лінгвістики: поняття і терміни. Донецьк : ДонНУ, 2012. Том 1. 402 с.

6. Космеда Т. Аксіологічні аспекти прагмалінгвістики: формування і розвиток категорії оцінки : монографія. Львів : ЛНУ ім. І. Франка, 2000. $350 \mathrm{c}$.

7. Космеда Т. Переднє слово, або «морфологія оцінки» О.В. Халіман. Граматика оцінки: морфологічні категорії української мови : монографія. Харків : Майдан, 2019. С. 7-12.

8. Космеда Т.А., Халіман О.В. «Граматика оцінки» як актуальна проблема сучасного мовознавства. Лінгвістичні студіі. Донецьк : Донец. нац. ун-т, 2011. Вип. 22. С. 17-23.

9. Космеда Т.А., Халіман О.В. Мовна гра в парадигмі інтерпретативної лінгвістики. Граматика оцінки. Граматична ігрема (теоретичне осмислення дискурсивної практики) : монографія. Дрогобич : Коло, 2013. 228 с.

10. Краснобаєва-Чорна Ж. Л Лінгвофраземна аксіологія: парадигмально-категорійний вимір : монографія. 2-е вид., випр. і доп. Вінниця : ТОВ «Нілан-ЛТД», 2016. 416 с.

11. Маркелова Т.В. Прагматика и семантика средств выражения оценки в русском языке : монография. Москва : Москов. гос. ун-т печати им. Ивана Федорова, 2013. 299 с.

12. Приходько Г.І. Категорія оцінки в контексті зміни лінгвістичних парадигм : монографія. Запоріжжя : Кругозор, 2016. 200 с.

13. Рязанцева Д.В. Прикметник сучасної української мови у вимірах граматики оцінки : дис. ... канд. філол. наук : 10.02.01. Харків, 2013.

14. Столярова Э.А. Лексико-семантическое поле оценки в разговорной речи. Словарные категории : сб. статей. Москва : Наука, 1988. C. $186-191$.

15. Халіман О.В. Граматика оцінки: морфологічні категорії української мови : монографія. Харків : Майдан, 2019. 458 с.

16. Шаховский В.И. Категоризация эмоций в лексикосемантической системе языка, изд. 2, испр. и доп. Москва, URSS, 2008. $208 \mathrm{c}$.

17. Bally Charles. Traité de Stylistique Française. (3rd. ed., 2 vol.) Paris : C. Klincksiek. 1951. 264 p.

18. Bally Charles. Le langage et la vie. Atar, 1913. 111 p.

19. Bally Charles. El Lenguaje y la Vida. (5th. ed.) Buenos Aires : Losada. 1967. 250 p. 
20. Bara B. Cognitive Pragmatics: The Mental Processes of Communication. USA : MIT Press, 2010. 485 p.

21. Bednarek Monika. Evaluation and cognition: Inscribing, evoking and provoking opinion. Language and Memory. Aspects of Knowledge Representation / Hanna Pishwa (ed.). Berlin : Mouton de Gruyter. 2006. P. 187-221.

22. Bednarek Monika (ed.). Evaluation in Text Types. Special Issue of Functions of Language 15.1. Amsterdam : John Benjamins. 2008. 192 p.

23. Bednarek Monika. Emotion Talk across Corpora. New York : Palgrave Macmillan. 2008. 242 p.

24. Bednarek Monika. Dimensions of evaluation. Cognitive and linguistic perspectives. Pragmatics and Cognition. 17 (1). 2009. P. 146-175.

25. Bednarek Monika. Emotion talk and emotional talk: Cognitive and discursive perspectives. Language and Social Cognition. Expression of the Social Mind / Hanna Pishwa (ed.). Berlin : Mouton de Gruyter. 2009. P. 395-431.

26. Breeze R., Olza I. Evaluation in media discourse. European perspectives. Berlin : Peter Lang, 2017. 286 p.

27. Cotos Elena. Genre-based automated writing evaluation for L2 research writing: From design to evaluation and enhancement. Basingstoke, UK : Palgrave Macmillan. 2014. 283 p.

28. Coseriu Eugenio. Principios de Semántica Estructural. Madrid : Gredos. 1977. 246 p.

29. Englebretson Robert. Stancetaking in Discourse. Amsterdam/Philadelphia : John Benjamins. 2007. 323 p.

30. Felices-Lago Ángel. The integration of the axiological classeme in an adjectival lexicon based on Functional-Lexematic principles. A Fund of Ideas: Recent Developments in Functional Grammar / Christopher S. Butler, John H. Connolly, Richard A. Gatward and Roel M. Vismans (eds). Amsterdam : IFOTT. 1997. P. 95-112.

31. Felices-Lago Ángel. Reformulation of the domain-level semantic pattern of axiological evaluation in the lexicon of English verbs. Hermes 30. 2003. P. 179-198.

32. Geckeler Horst. Strukturelle Semantik und Wortfeldtheorie. Munich : Fink. 1971. 255 p.

33. Guiraud Pierre. La Sémantique. Paris : P.U.F. 1955. 118 p.

34. Halliday Michael and Christian M.I.M. Matthiessen. Introduction to Functional Grammar. Third edition. London : Edward Arnold. 2004. 689 p.

35. Hidalgo Downing Laura. Grammar and Evaluation. The Encyclopedia of Applied Linguistics / Edited by Carol A. Chapelle. December 2015. URL: https://doi.org/10.1002/9781405198431.wbeal1471 (дата звернення: 13.11.2020). 
36. Hoey Michael. On the surface of discourse. London : George Allen and Unwin. 1983. 219 p.

37. Hood Susan. Appraising Research: Taking a stance in academic writing. Sydney : University of Technology. PhD thesis. 2004. 227 p.

38. Hunston Susan. Corpus Approaches to Evaluation: phraseology and evaluative language. Routledge. 2011.212 p.

39. Hunston Susan. Evaluation and Ideology in Scientific Writing. Register Analysis: Theory and practice / ed. Mohsen Ghadessy. London : Pinter. 1993. P. 57-73.

40. Hunston Susan. Evaluation and the planes of discourse: Status and value in persuasive texts. Evaluation in Text / ed. Susan Hunston and Geoff Thomson. Oxford and New York : Oxford University Press. 2000. P. 176-206.

41. Hunston Susan. Language patterns and ATTITUDE revisited: adjective patterns, attitude and appraisal. Functions of Language. 26, 3. 2019. P. 343-371.

42. Hunston Susan. Patterns, constructions and local grammar: a case study of "evaluation". Applied Linguistics. 40, 4. 2019. P. 567-593.

43. Hunston Susan. The evaluation of status in multi-modal speech. Functions of Language 15. 2008. P. 64-83.

44. Jordan Michael. Some discourse patterns and the signalling of the Assessment-Basis relation. Patterns of text: in honour of Michael Hoey I Eds. Mike Scott and Geoff Thompson. Amsterdam : John Benjamins. 2001. P. 159-92.

45. Krzeszowski Tomasz P. The axiological aspect of idealized cognitive models. Meaning and Lexicography / Jerzy Tomaszczyk and Barbara Lewandowska (eds). Amsterdam : John Benjamins. 1990. P. 135-165.

46. Krzeszowski Tomasz P. The axiological parameter in preconceptual image schemata. Conceptualizations and Mental Processing in Language I Richard A. Geiger and Brygida Rudzka-Ostyn (eds). Berlin : Mouton de Gruyter. 1993. P. 307-330.

47. Krzeszowski Tomasz P. Angels and Devils in Hell. Elements of Axiology in Semantics. Warsaw : Energeia. 1997. 298 p.

48. Labov William. Language in the inner city. Philadelphia : University of Pennsylvania Press. 1972. P. 354-396.

49. Lakoff G. Women, fire, and dangerous things. What Categories Reveal about the Mind. Chicago; London : The University of Chicago Pres. 1987. $614 \mathrm{p}$.

50. Lavelle Louis. Traité des Valeurs. (2 vol.). Paris : Presses Universitaires de France. 1950-1955. 560 p.

51. Le Senne René. Traité de Morale Générale. Paris : Presses Universitaires de France. 1942. 757 p. 
52. Martin James and White Peter. The Language of Evaluation. Appraisal in English. New York : Palgrave Macmillan. 2005. 278 p.

53. Martin J. Blessed are the Peacemakers: Reconciliation and Evaluation. Research and Practice in Professional Discourse / Christopher N. Candlin (Eds.). Tat Chee Avenue, Kowloon, Hong Kong : City University of Hong Kong Press. 2002. P. 187-227.

54. Martin J. Sense And Sensibility: Texturing Evaluation. Language, Education and Discourse: Functional Approache / Joseph A. Foley (Eds.). London : Nicholson Museum, University of Sydney. 2004. P. 270-304.

55. Martin J., Zappavigna M., Dwyer P. Negotiating evaluation: story structure and appraisal in youth justice conferencing. Appliable Linguistics / Mahboob, Ahmar and Knight, Naomi K. (Eds.). London : Continuum. 2010. P. 44-75.

56. Matoré G. La Méthode en Lexicologie. Domaine Français. Paris : Didier. 1953. $127 \mathrm{p}$.

57. Ortega y Gasset José. 1923. "Introducción a una estimativa: ¿qué son los valores?". Revista de Occidente. IV, October. Madrid : Revista de Occidente. 1947. P. 315-335.

58. Osgood Charles. The cognitive dynamic of synaesthesia and metaphor. Cognition and Figurative Language / Richard P. Honek and Robert R. Hoffman (eds). Hillsdale, New Jersey : Lawrence Erlbaum. 1980. P. 203-238.

59. Osgood Charles, Suci George and Tannenbaum Percy. The Measurement of Meaning. Chicago : Illinois University Press. 1957. 342 p.

60. Pottier Bertrand. Linguistique Générale. Théorie et Description. Paris : Klincksieck. 1974. 340 p.

61. Rokeach Milton. The Nature of Human Values. New York : The Free Press, McMillan. 1973. 438 p.

62. Sansome Rosemary. Connotation and lexical field analysis. Cahiers de Lexicologie. XLIX (II). 1986. P. 13-33.

63. Scheler Max. Der Formalismus in der Ethik und die Materiale Wertethik. 1913-1916. 872 p.

64. Sinclair John. Planes of discourse. The two-fold voice: essays in honor of Ramesh Mohan / ed. S.N.A. Rizvi. Salzburg : University of Salzburg. 1981. P. 70-89.

65. Stati Sorin. La Sémantique des Adjectifs: Essai d'Analyse Componentielle Appliqué aux Langues Romanes. Paris : Jean Favard. 1979. $144 \mathrm{p}$.

66. Thetela Puleng. Evaluated entities and parameters of value in academic research articles. English for Specific Purposes 16. 1997. P. 101-118. 
67. Trujillo Ramón. El Campo Semántico de la Valoración Intelectual en Español. La Laguna : University of La Laguna Press. 1970. 557 p.

68. Ullmann Stephen. Semantics. Oxford : Basil Blackwell. 1962. 278 p.

69. White P.R.R. Appraisal Theory. The International Encyclopedia of Language and Social Interaction / Tracy K. (Ed.). John Wiley \& Sons. 2015. P. 1-7.

70. White P.R.R. Evaluative contents in verbal communication. Verbal communication. 2016. Vol 3. P. 77-96.

71. Wotjak Gerd. Untersuchungen zur Struktur der Bedeutung. Berlin : Akademie-Verlag. 1971. 343 p.

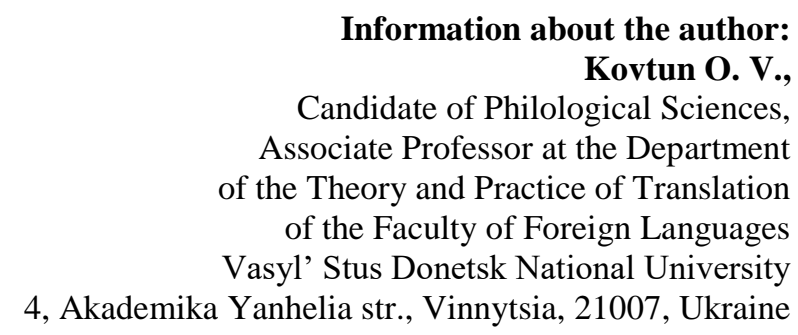

